\title{
Qualification Of Smuggling: Uzbek Legislation And Foreign Experience
}

Nodirbek Salaev, Tashkent State University of Law, Republic of Uzbekistan, https://orcid.org/0000-00022147-8762; nodirbek.salaev@tsul.uz

Nurmukhammad Khamidov, Editor at Portal International Scientific Journals Tadqiqot.uz Republic of Uzbekistan, https://orcid.org/0000-0002-9053-4174; n.hamidov@tsul.uz

\begin{abstract}
Uzbekistan is implementing comprehensive reforms aimed at radical reform and improvement of criminal law. In the Decree of the President of the Republic of Uzbekistan dated February 7, 2017 "On the Strategy of Actions for the Further Development of the Republic of Uzbekistan" PF-4947, also approved the Strategy for Improving the Strategy and Strategy is one of the directions. Despite the reforms, there is a need to improve the law on transnational crime due to the growing number of cases of transboundary movement of illicit goods or individuals that pose a serious threat to the interests of the state and society in order to gain material benefits. In addition, the Concept of Improving the Criminal and Criminal Procedure Legislation of the Republic of Uzbekistan, attached to the Resolution of the President of the Republic of Uzbekistan dated May 14, 2018 "On measures to radically improve the system of criminal and criminal procedure legislation" PP-3723 Due to the fact that measures should be taken and criminal law should include liability for transnational and international crimes, this scientific article is devoted to some issues related to the qualification of the crime of smuggling.The article also highlights the differences and similar features of the crime of smuggling from other similar crimes and analyzes the legislation of Uzbekistan. In addition, this article examines the specifics of the qualification of smuggling in the legislation of foreign countries as an object of study. Based on the general analysis, suggestions and recommendations are made on the classification of smuggling offenses based on the legislation of Uzbekistan.
\end{abstract}

Keywords: customs territory, law, smuggling, customs legislation, illegal crossing, declaration, legal rights.

$\begin{array}{lll}\text { Received: 08.12.2020 } & \text { Accepted: 11.01.2021 } & \text { Published: 01.02.2021 }\end{array}$

\section{INTRODUCTION}

This study is based on the fact that the criminal competition for smuggling and violation of customs legislation creates a competition of norms in the qualification of crimes committed by a person, ie the characteristics of a crime committed by a person simultaneously include elements of various norms of the Special Part of the CC. It is planned to investigate these crimes by comparing them.

This is due to the fact that the violation of customs legislation under Article 182 of the CC and the commission of smuggling in the customs territory, the completion of the crime with the illegal crossing of the state customs territory, as well as relations with foreign countries.

Therefore, first of all, it is necessary to analyze the constituent elements of the crime, which constitute the necessary and sufficient elements of these crimes: objective and subjective features. In particular, through a thorough analysis of the composition of the crime of violation of customs legislation, it is possible to develop reasonable proposals to improve the legislation on smuggling based on the identification of similarities and differences between violations of customs legislation and smuggling crimes.

The crime of violation of customs legislation is a social relationship related to the protection of the economic foundations of the Republic of Uzbekistan, according to Article 182 of Chapter XII of the Criminal Code the direct object of this crime is the basis of the established procedure for the movement of goods or other valuables across the customs border of the Republic of Uzbekistan.

According to the Resolution of the Plenum of the Supreme Court of the Republic of Uzbekistan "On Violation of Customs Legislation and Judicial Practice in Smuggling Cases", the subject of the crime of violation of customs legislation is any object of civil circulation, such as food, clothing. -what can be furniture, animals, etc. or material values [4].

Goods include any movable property, currency and currency assets, electricity, heat and other forms of energy, vehicles, intellectual property, as well as domestic and wild animals, including vehicles and other transport equipment used to transport passengers and goods not understood [3]. Only these 
goods are the subject of a crime of violation of customs legislation, and the relationship of the license, stamp, seal is not considered a crime of violation of customs legislation.

Other values include numismatics, antiques, works of art, paleontological remains of special historical, artistic, scientific or cultural significance, regardless of their type, status and value, and their historical, artistic, scientific or cultural significance. to be carried out through the appointment of appropriate expertise [4].

After the imposition of an administrative penalty, the objective aspect of the crime of violation of customs legislation is to evade customs control or conceal it from customs control or by using fraudulent documents or documents similar to customs documents or means, or without a declaration or other declaration. is represented by crossing the boundary. A necessary indication of this crime by the objective is that criminal liability for the act arises when it is committed in large quantities within one year after the imposition of an administrative penalty for the same act.

The customs border of the Republic of Uzbekistan does not correspond to the state border of the country, as it is determined not only by the border of the Republic of Uzbekistan, but also by free customs zones and free warehouses on the territory of Uzbekistan. These areas are considered to be located outside the customs territory of the Republic of Uzbekistan, the borders of the customs territory, as well as free customs zones and free warehouses are the customs border.

Crossing the customs border means the movement of goods or means of transport into or out of the customs territory by any means, including the sending of international mail, the use of pipelines and power transmission lines. According to Article 7 of the Customs Code of the Republic of Uzbekistan, the actions of import or export into the customs territory include:

- by practical crossing of the customs border when goods or means of transport are brought into the customs territory, including from the territory of free customs zones and free warehouses;

- when goods or means of transport are removed from the customs territory, including free customs zones and free warehouses.

The crime of violation of customs legislation is expressed by the lens in actions such as evasion of customs control of goods or other valuables, concealment from customs control, fraudulent use of documents or declaration.

Avoidance of goods or other valuables by customs control means their removal from the place where the customs authorities are not present or outside the time of customs clearance and control.

Concealment from customs control means the transfer of goods or other valuables transported by a person across the customs border in secret places and using methods that make it difficult to find, or by giving the appearance of one type of goods to another. Particular attention should be paid to the method of concealment of property in special storage areas, which may include secret areas, as well as containers and other items of design and capacity equipped and adapted to vehicles for smuggling purposes, preprocessed, collected and so on.

The fraudulent use of documents means the submission to the customs control of forged documents, documents obtained by illegal means or documents with false information as a basis for the movement of goods, goods and other valuables across the customs border. A document obtained by illegal means is a document obtained in violation of the established procedure or by providing false information or as a result of committing an illegal act.

The act of fraudulent use of means of customs identification is characterized by change, destruction, damage or loss of means of identification imposed by the customs authorities of the Republic of Uzbekistan or other state bodies.The means of customs identification may be changed or destroyed only by the customs authorities. Except when there is a real risk of damage or irreparable damage or loss of goods or vehicles. Also, illegal change of customs identification means may be related to their forgery.

Declaration means the realization of accurate information about goods or means of transport, the customs regimes in which they are placed, and other information required for customs purposes in the prescribed form. After all, from the moment of registration of the adoption of the customs declaration, it becomes a document certifying the facts of legal significance. Non-declaration of goods or other valuables or declaration under different name means actions of persons in connection with violation of the procedure for declaration of smuggled goods or other valuables, ie the form and place of declaration established by customs legislation, the procedure for its implementation non-compliance with the requirements for the deadlines for submission of declarations and other additional documents, as well as the inclusion of false information in the declaration on the type and quantity of smuggled goods, goods or other valuables imported into or exported from the territory of the Republic of Uzbekistan.

From the moment the goods are illegally transported across the customs border of the Republic of Uzbekistan, the crime of violation of customs legislation is considered completed because it is not a crime of a material nature [5]. 
The crime of violation of customs legislation is subjectively characterized by the fact that the crime was committed intentionally, the guilty person realizes that the goods or valuables are being smuggled across the customs border, and wants to achieve his criminal purpose. The motive and purpose of the person who committed a socially dangerous act in the classification of this crime shall not affect the qualification of the crime.

The subject of the crime may be any sane individual over 16 years of age.

On the basis of the above considerations, toxic, poisonous, radioactive, explosive substances, explosive devices, weapons, which have a strong effect, by bypassing or concealing from customs control or by fraudulently using documents made in the form of customs documents or means, without a declaration or other written declaration. - smuggling of weapons, firearms or ammunition, as well as drugs or psychotropic substances or materials promoting religious extremism, separatism and bigotry across the customs border of the Republic of Uzbekistan entails criminal liability under Article 246 of the Criminal Code..

Qualification of the analyzed crime according to aggravating circumstances in part 2 of Article 182 of the Criminal Code:

- in large quantities;

- crossing the border, ie by openly moving goods or other valuables across the customs border of the Republic of Uzbekistan without the consent of the customs service;

- by an organized group or in its interests;

- is committed using a service position.

If we analyze the norms provided for in the second part of the crime of violation of customs legislation, we can see that they are expressed in sequence according to the objective and subjective features of the crime, and the social risk of each element is increased compared to the first part.

The open transfer of the items listed in the first part of the second part of Article 182 of the Criminal Code means the awareness of customs officers about the movement of goods. Awareness of the customs service arises from the submission of information that violates the provisions of the legislation and the direct control of the customs authority. If the culprit is not aware of the fact that the customs service is aware of the illegal movement of goods or valuables, the act is not considered open transfer. The open movement of goods must also be carried out without the permission of the customs service, ie there must be no official permission to carry out such an action.

According to the second part of Article 182 of the Criminal Code, in relation to violations of customs legislation, the liability includes not only persons transporting goods or other valuables directly across the customs border, but also all members of the organized group. For example, those who bought for the purpose of smuggling across the customs border, or those who bought with the knowledge that they were smuggled after the smuggling.

It is also a crime to violate customs legislation in the interests of an organized group as a result of the prior purchase of goods or valuables imported from abroad by a person who is not a member of the organized group.

Part 2 of Article 182 of the Criminal Code establishes liability for violation of customs legislation using the powers of the service, regardless of the amount of damage. Violation of the customs legislation by using the powers of the service is the movement of goods and other valuables across the customs border by an official of the customs authorities, ie a person entrusted with the control function and other obligations under the customs legislation. The use of official authority also means that the violation of customs legislation is committed through the abuse of power by officials of other government agencies.

According to the Decree of the Plenum of the Supreme Court of the Republic of Uzbekistan "On judicial practice in cases of violation of customs legislation and smuggling", the subject of the crime under Article 182 (2) (g) persons who have abused their power or official position for the purpose of illegal movement of goods and other valuables across the border of the Republic of Uzbekistan [4].

Based on the above analysis of the components of the crime of violation of customs legislation, it is possible to understand the following similar aspects of the violation of customs legislation and smuggling in the case of research.

First, violations of customs legislation and smuggling crimes are objectively committed by the customs border, ie the borders of the customs territory, as well as the free use of goods or means of transport in any way, including international mail, pipelines and power transmission lines. is represented in the performance of actions such as importation or exportation.

Second, the violation of customs legislation and the crime of smuggling are considered to be completed by the smuggling of goods across the customs border, which is a formally objective crime, ie the occurrence of any harmful consequences that do not necessarily affect the qualification of the crime. . 
In these crimes, the consequences of the use of goods after their movement across the state border or the consequences of their import or export are considered insignificant in the qualification of the act.

Third, according to Article 17 of the Criminal Code, the subject of violation of customs legislation and smuggling is a sane physical person who has reached the age of 16

Fourth, the violation of customs legislation and smuggling are subjectively committed intentionally, when the perpetrator realizes that the goods or valuables are being smuggled across the customs border and wants to pursue his criminal goal.

Due to the violation of the above-mentioned customs legislation and similar aspects of smuggling crimes, there is a normal competition in the qualification of the act in the investigative and judicial bodies.

Also, based on the views on the analysis of the components of the crime of violation of customs legislation, it is possible to understand the following different aspects of violations of customs legislation and smuggling in the case of research [5].

First, violations of customs legislation and smuggling crimes differ significantly in terms of the subject matter of the crime.

The crime of violation of the customs legislation causes damage to the social relations of the state in the economic sphere, the subject of which is any commodity or material value in civil circulation; the crime of smuggling to the detriment of the public relations of the state related to public safety means, their analogues or psychotropic substances, materials promoting religious extremism, separatism and bigotry, nuclear, chemical, biological and other types of weapons of mass destruction, in the creation of such weapons materials and devices that are known to be usable as well as radioactive materials.

Second, in the crime of violation of customs legislation, the value of the goods that are the subject of the crime plays an important role; if the value of the goods is a large quantity, according to the first part of Article 182 of the CC, if the quantity is a large quantity, it is determined to qualify according to the second part of Article 182 of the CC.

In the case of smuggling, the amount of smuggled items does not play a legal role in the qualification of the act. Indeed, smuggled goods are considered dangerous to society, regardless of their quantity, and their illegal import from the state border or their illegal use for transit purposes poses a serious threat to the legally protected interests of the individual, the state and society.

Thirdly, if the crime of violation of customs legislation is expressed in the fact that the crime is committed in large quantities within a year after the imposition of an administrative penalty for the same act, the administrative penalties for the crime due to the high social risk of smuggling The Republic of Uzbekistan is not provided

Fourth, the decision of the Plenum of the Supreme Court "On Judicial Practice in Cases of Violation of Customs Legislation and Smuggling" This principle does not apply to the fact that the crime of smuggling is committed by falsifying documents or entering false information in customs documents.

Fifth, the crime of violation of customs legislation is differentiated by the legislature, which stipulates that the act committed in the first part of Article 182 of the CC is qualified by the second part of Article 182 of the CC when committed in a dangerous manner according to objective or subjective criteria. However, the legislature does not provide for the differentiation of the acts provided for in the first part of Article 246 of the Criminal Code on the basis of objective or subjective indications that they are dangerous.

Sixth, while the legislature provides for criminal liability for violating customs legislation by violating the border or using force, there is no criminal liability for smuggling for violating the border or forcibly using a lawful request of a public official.

Seventh, while the crime of violation of customs legislation provides for criminal liability for violation of customs legislation by an official of the competent state body, the crime of smuggling does not provide for criminal liability for smuggling using the official position of an authorized state body.

Foreign experience

In order to develop reasonable proposals for improving the smuggling legislation of the Republic of Uzbekistan, it is expedient to study the smuggling legislation of the Republic of Uzbekistan on the basis of the results of trade turnover with foreign countries by the end of the year. The volume of foreign trade between the states is carried out through the movement of goods across the state border, creating conditions for the commission of crimes such as smuggling of large quantities of goods requires.

The volume of foreign trade of the Republic of Uzbekistan in 2019 amounted to $\$ 42.2$ billion, of which $\$ 17.9$ billion - exports, \$24.3 billion - imports, accounting for $18.1 \%$ of the country's foreign trade turnover or $\$ 7.6$ billion. . In 2019 , the Russian Federation accounted for $15.7 \%$ or $\$ 6.6$ billion of the state foreign trade turnover of the Republic of Uzbekistan, and Uzbekistan exported \$ 2.4 billion and imported $\$ 4.1$ billion to Russia47. 
China. Criminal law issues in the People's Republic of China are regulated by the Criminal Code, adopted on March 14, 1997 at the V session of the VI Convocation of the National People's Congress of China. Articles 151-157 of the Chinese Criminal Code prohibit social relations related to smuggling with the threat of punishment, and criminal liability for the acts listed in these articles differs according to their object.

According to the first part of Article 151 of the Criminal Code of China, smuggling of weapons, ammunition, nuclear materials or counterfeit currency is punishable by imprisonment for more than 7 years, including confiscation of property; when the offenses are committed in mitigating circumstances, they are punishable by three to seven years in prison and a fine.

The second part of Article 151 of the Criminal Code provides for imprisonment for more than five years for illegal import of cultural property, gold, silver and other precious metals, as well as valuable animals and their products, which are prohibited by the state. such actions are punishable by up to five years in prison and a fine if committed in mitigating circumstances.

Also, according to the third part of Article 151 of the Criminal Code, the export of rare plants and their products is punishable by imprisonment for a term of up to five years or a fine of up to five years in mitigating circumstances. punished with.

It is noteworthy that the acts listed in Article 151 of the CPC differ according to the subject of the object, and the fourth part of the article stipulates that the offenses specified in the first and second parts, especially in aggravating circumstances, are punishable by life imprisonment or confiscation of property.

Article 151 of the Criminal Code of China establishes criminal liability for illicit trafficking, according to which the object of the crime of smuggling is social relations related to ensuring public safety. In China, weapons, ammunition, nuclear materials or counterfeit currency, cultural property, gold, silver and other precious metals, precious animals and articles made of them are classified according to the subject of smuggling and illegally imported or exported under Article 151 of the Criminal Code. , as well as unique plants and products made from them.

The crime of smuggling is characterized by the illegal importation of items prohibited by the laws of the People's Republic of China from the state border. The subject of this crime can be both an individual and a legal entity. According to the fourth part of Article 151 of the Criminal Code, if smuggling is committed by an organization, the organization is subject to punitive measures, as well as criminal liability of the directors of the organization and those directly responsible.

China also criminalizes the smuggling of pornographic films, video tapes, audio tapes, photographs, printed materials and other pornographic materials under Article 152 of the Criminal Code. the subject is considered to have a negative impact on the normal conscious development of the juvenile stratum of the Chinese people.

It is also smuggled into China and smuggled across the state border. According to the Criminal Code, the following actions are considered smuggling:

- illegal purchase of goods prohibited by the state from smuggling, or illegal purchase of other goods and items imported into the country in relatively large quantities;

- transportation, purchase, resale of products prohibited for import and export by the state, or transportation, purchase, resale of relatively large quantities of goods and objects prohibited for import and export by the state without legal permission;

- importation of solid household waste from abroad, not approved by the customs authorities;

- to deal with smuggling, to give him a loan, money, account, check, certificate or to provide transport, warehousing and postal services;

- concealment of smuggling with a weapon.

Under Chinese criminal law, preventing smugglers from being apprehended with threats and violence is punishable as a set of crimes under the articles designated for smuggling and obstructing government officials in the performance of their duties.

Chinese criminal law also stipulates that smuggling of other goods and items may result in penalties depending on the severity of the situation.

In China, if the smuggling act is repeated and the penalty is not pre-determined, the crime is punished according to the amount of tax paid on the sum of all smuggled goods and items.

Russia. Illegal import or export of goods prohibited in the Russian Federation is a crime of smuggling and is punishable by a threat of punishment under the Russian Criminal Code. According to him, smuggling is classified under Articles 2261 and 2291 of the Criminal Code [1]. The first part of Article 2261 of the Criminal Code provides for strong, toxic or poisonous, explosive, radioactive substances or their sources, nuclear materials, firearms and their main parts, explosive devices, ammunition, weapons of mass destruction, means of their delivery, as well as materials and equipment that can be used to create weapons of mass destruction,the means of their delivery, as well as large 
quantities of strategically important goods and resources or cultural resources, or (or) valuable species of wildlife and aquatic biological resources protected by international treaties of the Russian Federation.

Article 2261 of the Criminal Code is differentiated, according to which the aggravating circumstances of the acts provided for in the first part of Article 2261 of the Criminal Code are provided in the second part, which are as follows:

- an official using his official position;

- cases of violence against a person carrying out customs or border control.

Also, according to the third part of Article 2261 of the Criminal Code, the commission of the acts provided for in the first or second part of this article by an organized group requires a special qualification of the act.

The list of strategically important goods provided for in Article 226 of the CC is approved by the Government of the Russian Federation, according to which a large number of strategically important goods and resources are recognized as a large quantity for certain types of goods when their value exceeds one hundred thousand rubles. is determined to be obtained [2].

The first part of Article 229 of the CC provides for the production of narcotic drugs, psychotropic substances, their analogues or their analogues, plants containing narcotic drugs, psychotropic substances or their analogues, under special control and under the control of narcotic drugs or psychotropic substances within the Eurasian Economic Community. criminal liability for illegal transportation of used equipment across the state border. Article 2291 of the Criminal Code is also differentiated, according to which the aggravating circumstances of the acts provided for in the first part of Article 2291 of the Criminal Code are considered in the second part, which are:

- pre-arranged by a group of individuals;

- using his official position;

- narcotic drugs, psychotropic substances or their analogues, plants containing narcotic drugs, psychotropic substances or parts containing narcotic drugs or psychotropic substances.

Also, according to the third part of Article 2291 of the Criminal Code, the actions provided for in the first or second part of this article are much more severe than drugs, psychotropic substances, their analogues or analogues, drugs, psychotropic substances or their analogues, plants or narcotic drugs, psychotropic substances or their parts criminal liability has been established for the amount committed.

The actions provided for in the first, second or third parts of this article:

- by an organized group;

- in large quantities in relation to narcotic drugs, psychotropic substances, their analogues or analogues, narcotic drugs, psychotropic substances or their analogues or parts containing narcotic drugs, psychotropic substances or their analogues;

- in case of violence against a person carrying out customs or border control, it is determined to qualify in accordance with the fourth part of Article 2291 of the Criminal Code.

The crime of smuggling under Articles 2261 and 2291 of the Criminal Code is objectively expressed in the illegal movement or entry of prohibited goods through the customs border of the Customs Union within the Eurasian Economic Community or with the member states of the Customs Union of the Russian Federation. The act can be done in the following ways:

- outside the designated places of movement of goods or in cases when the working hours of the customs authorities are not established in these places;

- concealing from customs control;

- without the necessary documentation or declaration;

- using counterfeit or other means of identification of goods

According to the Criminal Code of the Russian Federation, the crime of smuggling is considered to have been committed from the moment of the attempt to smuggle one of the objects of this crime.

The crime of smuggling is committed intentionally by a subjective, and the subject of the crime is a sane individual.

In the Russian Federation, smuggling differs according to the subject of the crime, and the following are recognized as the subject of Article 2291 of the Criminal Code:

- drugs;

- psychotropic substances;

- analogues of narcotic drugs or psychotropic substances;

- analogues of narcotic drugs or psychotropic substances;

- plants containing narcotic drugs, psychotropic substances or their analogues;

- parts of plants containing narcotic drugs, psychotropic substances or their analogues;

- instruments and equipment under special control and used in the manufacture of narcotic drugs or psychotropic substances. 
The analogues included in Tables I and II of the "List of controlled drugs, psychotropic substances and their analogues in the Russian Federation", approved by the Government of the Russian Federation on June 30, 1998 No. 681, are also subject to smuggling.

The subject of Article 2291 of the Criminal Code is the items, substances, materials and equipment specified in this article, regardless of their value, as well as goods and resources of strategic importance or cultural property.

According to Article 2291 of the Criminal Code, intentional infliction of minor or moderate bodily injury by beating a person engaged in customs or border control, causing physical pain or other acts of violence, the Special Part of the Criminal Code does not require additional qualification with other articles.

In conclusion, the above allows us to offer a general description of the concept of smuggling, which is punishable under the theory of criminal law [5]. Smuggling means an action or inaction associated with the illegal transfer or transportation by secret methods across the state customs border of items withdrawn from free civil circulation or restricted in free circulation, as well as the legalization of the transportation of such goods and items by abuse of their official duties.

\section{References}

1. The Criminal of ode the Russian Federation. http://www.consultant.ru/document/cons_doc_LAW_10699.

2. http://ukodeksrf.ru/ch-2/rzd-9/gl-24/st-226-1-uk-rf

3. Article 7 of the Civil Code of the Republic of Uzbekistan. https://lex.uz/docs/111189

4. Resolution of the Plenum of the Supreme Court of the Republic of Uzbekistan "On judicial practice in cases of violation of customs legislation and smuggling" https://www.lex.uz/docs/2259789

5. Khamidov Nurmukhammad Orif ugli. The concept of smuggling and social necessity of criminal liability for smuggling. Journal of Law Research. 2019, 9 vol., issue 1, pp. 94-102

6. Shokhrud F. Fayziev The problem of social stigma during a pandemic caused by COVID-19 International Journal of Advanced Science and Technology Vol. 29, No. 7, (2020), pp. 660-664 http://sersc.org/journals/index.php/IJAST/article/view/13965/7188

7. Fayziyev Shokhrud Farmonovich Medical law and features of legal relations arising in the provision of medical services. International journal of pharmaceutical research Volume 11, Issue 3, July - Sept, 2019 P. $1197-1200 \quad$ doi:10.31838/ijpr/2019.11.03.088 http://www.ijpronline.com/ViewArticleDetail.aspx?ID=11016

8. Bryanskaya Elena, Fayziev Shokhrud, Altunina Anna, Matiukha Alena Topical Issues of an Expert Report in the Process of Proving in a Criminal Examination. International Journal of Engineering and Advanced Technology (IJEAT) ISSN: 2249 - 8958, Volume-9 Issue-1, October 2019 5345-5349 DOI: 10.35940/ijeat.A2946.109119

a. https://www.ijeat.org/wp-content/uploads/papers/v9i1/A2946109119.pdf

9. Fayziev Shokhrud (2019) Legal Aspects of Transplantology in the Republic of Uzbekistan. Systematic Reviews in Pharmacy, ISSN: 0976-2779, Vol: 10, Issue: 2, Page: 44-47 doi:10.5530/srp.2019.2.08 http://www.sysrevpharm.org//fulltext/196-1575419211.pdf?1586863081

10. Tulaganova, G. Some issues of observance of international legal norms of fight against legalization of criminal incomes in the Republic of Uzbekistan Journal of Advanced Research in Dynamical and Control Systems 12(2 Special Issue), c. 143-155

11. Bazarova D. Some problems of counteracting crimes related to laundering of illegal proceeds in Uzbekistan \ournal of Advanced Research in Dynamical and Control Systems. Volume 11, Issue 7, 2019, Pages 873-885 